\title{
Vaginal Cancer pT4 TNM Finding v7
}

National Cancer Institute

\section{Source}

National Cancer Institute. Vaginal Cancer PT 4 TNM Finding v7. NCI Thesaurus. Code C89465.

Vaginal cancer invading the mucosa of the bladder or rectum and/or extending beyond the true pelvis (bullous edema is not sufficient evidence to classify a tumor as T4). (from AJCC 7th Ed.) 